\title{
Soča Fidler
}

Univerza v Ljubljani

Pedagoška fakulteta

\section{The Portfolio - a More Responsible Student - a Less Stressed-out Teacher}

Summary

The article warns against the negative impacts of external assessment. These impacts are already noticeable in Slovenia, specifically and mainly in the teaching approach and learning efforts used for taking the standardised Matura exams. There is a narrowing of overall learning goals and a neglecting of the areas that, although vital for students' development, are not assessed in the exams themselves; as well, there are increased stress levels before and during the exams, which could result in a poorer performance. The article then proposes a portfolio approach in which students set their own learning goals, pursue them, reflect both on their achievements and alternative ways to make better progress. The portfolio approach lends itself extremely well to developing a student's writing skills gradually, as the awareness of learning goals and the setting of one's own, in combination with self-assessment and reflection are better motivators than just following preset objectives.

Key words: portfolio, learning goals, self-assessment, reflection, autonomy

\section{Portfolio - bolj odgovoren učenec (študent) - manj obremenjen učitelj}

Povzetek

Članek opozarja na negativne učinke zunanjega preverjanja, ki se že kažejo tudi v Sloveniji, kot so poučevanje in učenje za maturo in s tem ožanje učnih ciljev ter zanemarjanje vsebin, ki niso preverjane na maturi (vendar so še kako pomembne za učenčev razvoj), pa tudi povečan stres pred in $\mathrm{v}$ času izpitov ter za marsikaterega učenca zaradi tega tudi slabši rezultati. V nadaljevanju predlaga portfolijski pristop z zastavljanjem osebnih učnih ciljev, zasledovanjem le-teh, refleksijo o doseženem ter možnih načinih za boljši lastni napredek. Portfolijski pristop je nadvse primeren za postopno razvijanje pisne zmožnosti, pri čemer uzaveščanje in zastavljanje učnih ciljev, samo-ocenjevanje ter refleksija motivirajo dijake bolj kot zgolj zasledovanje vnaprej določenih ciljev.

Ključne besede: portfolio, učni cilji, samoocenjevanje, refleksija, avtonomija 


\section{The Portfolio - a More Responsible \\ Student - A Less Stressed-out Teacher}

\section{Introduction}

With Slovenia joining the EU, the comparability of knowledge and competences of its citizens is not only desired but also essential, if mobility and thus the exchange of knowledge are to be enabled or even encouraged. The Slovene education system has traditionally been more focused on acquiring knowledge than developing competences and skills; therefore demands for change have been put forward more frequently over the last two decades. A rather radical move in the direction of laying more emphasis on competences was made with the introduction of external examinations at the secondary level in 1995, namely through the standardized Matura, which was aimed at higher-order thinking skills. At the beginning, this secondary-school leaving exam consisting of five subjects brought about some positive changes, as secondary school teachers keenly attended Matura seminars in order to find out more about the format of the exam as well as about the suggested methods for reaching the Matura objectives effectively and in a student-friendly manner. One of the primary aims of making Slovene secondary schools more comparable in terms of the desired learning outcomes seemed to have been successfully pursued, if not reached.

However, very soon after the introduction of the Matura, some English teachers started to warn the testing committee of the danger of losing a creative dimension in the teaching process, as classroom activities were mainly targeted at teaching to the tests. This was more or less an expected result, as the Matura scores are attached to 'high stakes' (enrolment in most of the faculties depends on the number of the achieved points in the Matura). What was experienced in Slovene secondary schools seemed to be very similar to what had been reported about the negative consequences of external testing elsewhere in the world, e.g. in Canada and the USA (Koretz, Stecher, Anderson, Bachor, 1998; Linn, 2000): though exam results were satisfactory, they came at the expense of innovative forms of instruction. "Areas particularly neglected are those related to creativity and personal and social development" (Gordon \& Reese 1997; Leonard \& Davey 2001 in Harlen 2003, 199). "Even when not teaching directly to the tests, teachers reported changing their approach. They adjusted their teaching in ways they perceived as necessary because of the tests, spending most time in direct instruction and less in providing opportunity for students to learn through enquiry and problem-solving" (Johnston \& McClune 2000 in Harlen 2003, 199). "The review of Deci and Ryan (1985) also provides research evidence that assessment of the kind that takes away control from the learners reduces intrinsic motivation and leads to 'surface' learning" (Harlen 2003, 171). Moreover, "there was considerable evidence from a range of countries and across academic subjects, of a negative relationship between test anxiety and test performance" (ibid., 172). The Slovene public, mainly composed of informed and worried parents, also started to raise their voices against this race for points, which leads to a lot of additional stress for the whole family. 
In 1998, almost at the same time as the first negative effects of external testing in Slovenia were noticed and drawn attention to, a European language portfolio project was started. The language portfolio launched by the Council of Europe was a relatively novel tool, although general portfolios as its forerunners had been present in Great Britain, the United States and Canada for a few decades, struggling to fill the gap between the benefits and disadvantages of external testing, which was still seen by many testers as a necessary - i.e. the most reliable and valid way - of assessment. The language portfolio, despite some shortcomings, does seem to be a promising document that gives students and teachers some of their well deserved autonomy in the classroom, and could be considered a valid means of continuous assessment, encouraging students to invest conscious effort in learning throughout their education, thus hopefully equipping them with the necessary strategies for lifelong learning. In the continuation of the paper, two proposals will be made: one, to integrate the language portfolio assessment of the writing skill into the English Matura (or preferably, the Matura in foreign languages as the procedure could apply to any foreign language) as one of its component parts; and another, to include university students' individual work as an obligatory part that will carry a certain weight in the final grade.

\section{Portfolio approach - a way to learner independence \\ 2.1 Self-assessment}

The European Language Portfolio is a personal document of students' achievements and progress, which helps students compare their levels of language competences and skills with those described in the Common European Framework of Reference for Languages. It is a valuable instrument designed for developing student responsibility towards their own learning, thus boosting their self-confidence, and assisting the teacher, as students set their own objectives within the set curriculum or even beyond it. It encourages self-teaching and studentcentredness and contains a six-level assessment scale intended for the student's self-assessment (self-evaluation) and the teacher's co-assessment.

Assessment is important information bearing serious consequences and requiring great responsibility on the assessor's part. It should be as accurate as possible and since tests and teachers are not sensitive enough to reflect small changes in the student's performance, it is only normal that it should involve the assessee as well. According to Heidt (1979 in Oskarsson 1992, 17), who wrote one of the first studies on self-assessment, informal self-assessment is an integral part of all human activities. The studies carried out at the beginning of the 1980s (Oskarsson 1992) showed that adults and university students are capable of assessing their language competences quite realistically. Von Elek's studies (1981, 1982 in Oskarsson, ibid.) also reported on increased learning motivation of adult learners during the self-assessment process. A more recent study (McDonald \& Boud 2003, 217) showed that "On average, students with self-assessment training outperformed their peers who had been exposed to teaching without such training in all curriculum areas." 
Classroom teachers qualified to teach English to young learners at the Faculty of Education in Ljubljana, when asked whether they would like to be able to assess their work, responded positively, although, later in the process, some of them said that the self-assessment experience was very useful but not tremendously enjoyable. A study carried out on a modest scale showed that in $62.5 \%$ of the cases the student's self-assessment without any prior training agreed with the teacher's assessment, which was sometimes based on the results of objective tests and sometimes only on her recollection of their work in class. In a discussion the students stated that they had felt insecure while assessing their work and expressed a wish to have test specimens for each level as guidance. $75 \%$ of the students included in the study claimed that the self-assessment check-lists motivated them to study. Indeed, a slightly better performance in writing, reading and listening was noticed while the students were intensively engaged in the portfolio approach (Fidler 2000).

Self-assessment, if trained over a period of time, and monitored by the teacher, seems to be quite a realistic goal. The secondary school curriculum for English foresees self-assessment (self-evaluation and self-assessment as part of the portfolio) as one of the assessment modes, so it can be assumed that self-assessment is to be encouraged and even incorporated into the final grade. It is also a way to slowly develop a student into a more responsible learner. 50\% of the students included in the study at the Faculty of Education, Ljubljana claimed they were becoming more responsible learners (did the others perhaps feel they were responsible even before or did they not experience any benefits?); what is more, $81.3 \%$ of those students liked their new responsibility. It is worth noting that a feeling of greater responsibility increased with the age of the students. $37.5 \%$ of the students also claimed they had become more active in the learning process in class (Fidler 2000). Further evidence in favour of self-assessment comes from the answers of the Slovene primary and university teachers who participated in the European Language Portfolio Project: 13 out of 18 teachers claimed that their students were capable of assessing their language competences (Čok in Fidler, Interim report on Portfolio of Languages in Slovenia, 2000).

\subsection{Example of introducing portfolio assessment at the secondary level}

One of the ways of motivating students for portfolio self-assessment at the beginning of the first year could be to reflect on the learning process and assessment, e.g.:

1. What do you think your role should be in the learning process?

2. What do you think the teacher's role should be in the teaching process?

3. Are you always happy with the marks that you get?

4. Would you like to be able to mark your work and then compare your mark with the teacher's? Why (not)?

5. What would you need to be able to assess your English (German, French etc.)?

6. Would you like to use the same self-assessment criteria as your peers in other European countries? Why (not)? 
After answering such questions in pairs, students are made aware that it is they who should be in charge of the learning process, not only at home but also at school. Generally, they are very enthusiastic about the possibility of being able to assess their work using the same self-assessment scales as students do in other European countries. They also come to the conclusion that in order to reach the goal of becoming competent assessors, they will need criteria, self-assessment scales and practice (standardisation).

The next step is to introduce students to the concept of different levels of competence. For example, students can be faced with a descriptor of reading comprehension at three levels (Little \& Perclová 2001) and asked to rank them from the lowest to the highest level (Here they are put in the right order but the teacher should present them in a mixed order to make students aware of the differences between them).

\section{EXAMPLE:}

I can understand the main points in short newspaper articles about current and familiar topics. (B1)

I can read and understand articles and reports on current problems in which the writers express specific attitudes and points of view.

\section{(B2)}

I can read complex reports, analyses and commentaries where opinions, viewpoints and connections are discussed.

(C1)

After students justify their decision on ranking the can-do statements, thus also being made aware of different objectives, they can be given the descriptors of the level they should have reached by the end of primary school (A2) to tick the statements, once if they are able to do a certain thing and twice if they can do that easily. In this way, students not only give important information about themselves to the foreign language teacher at the beginning of the year, but are also made to reflect on their own strengths and weaknesses and indirectly about their learning goals. "Research indicates that students with learning goals (also known as task involved or mastery goals) show more evidence of superior learning strategies, have a higher sense of competence as learners, show greater interest in school work and have more positive attitudes to school than do students with performance goals" (Ames 1990a, b; Dweck 1992 in Harlen 2003, 175). The teacher now gives students the self-assessment checklists of the next level (B1) and tells them that these are the goals they should reach in two years' time, some of them earlier and the others later. Students can read the descriptors for the next level at home and tick their objectives for that year. Setting oneself objectives is essential, but the teacher should tell the students to be realistic when setting objectives for themselves.

The range of skills and competences of one level is too broad, and being confronted with too many objectives is certainly frightening and off-putting for students, so afterwards the teacher and students should shorten the list to include more tangible, short-term objectives (attainable in half a year or a year, and in line with the syllabus). This is a good way for students to get to 
know what they will have to master by the end of the year, and they are guided, at least at the beginning, towards setting goals for themselves.

\section{Some examples of self-assessment checklists - B1 level}

(adapted Swiss version of the European Language Portfolio in Little \& Perclová 2001)
1 - Me
2 - My teacher

Use the symbols below in columns 1 and 2

$\sqrt{ }$ - I can do this under normal circumstances

$\sqrt{ } \sqrt{ }$ - I can do this easily

\section{3 - My objectives !}

\section{This is an objective for me!}

This is a priority for me!!

Me My teacher My obj.

\begin{tabular}{|c|c|c|c|}
\hline \multirow{2}{*}{ Reading comprehension } & $\mathrm{Me}$ & My teacher & My obj. \\
\hline & 1 & 2 & 3 \\
\hline \multicolumn{4}{|l|}{$\begin{array}{l}\text { - I can understand the main points in short newspaper articles } \\
\text { about current and familiar topics. (B1) }\end{array}$} \\
\hline \multicolumn{4}{|l|}{$\begin{array}{l}\text { - I can guess the meaning of single, unknown words from the } \\
\text { context if the topic is familiar. (B1) }\end{array}$} \\
\hline \multicolumn{4}{|l|}{$\begin{array}{l}\text { - I can understand the plot of a clearly structured story and } \\
\text { recognise what the most important episodes and events are } \\
\text { and what is significant about them. (B1) }\end{array}$} \\
\hline \multicolumn{4}{|l|}{ Listening comprehension } \\
\hline \multicolumn{4}{|l|}{$\begin{array}{l}\text { - I can understand the main points in TV programmes on familiar } \\
\text { topics when the delivery is relatively slow and clear. (B1) }\end{array}$} \\
\hline \multicolumn{4}{|l|}{$\begin{array}{l}\text { - I can listen to a short narrative and form hypotheses about } \\
\text { what will happen next. (B1) }\end{array}$} \\
\hline \multicolumn{4}{|l|}{ Language quality } \\
\hline \multicolumn{4}{|l|}{$\begin{array}{l}\text { - I have sufficient vocabulary to express myself with some } \\
\text { circumlocutions on most topics pertinent to my everyday } \\
\text { life. (B1) }\end{array}$} \\
\hline \multicolumn{4}{|l|}{$\begin{array}{l}\text { - I can pronounce newly taught words correctly. (Teacher's } \\
\text { proposal) }\end{array}$} \\
\hline $\begin{array}{l}\text { - I can use the present and past tense in the active and passive } \\
\text { correctly. (1st-year syllabus) }\end{array}$ & & & \\
\hline & & & \\
\hline
\end{tabular}

The blank box after each skill or competence is for students to add their own personal objectives and to make them think about them. The first column is meant for the student to assess his/her skill or competence later on in the process, whereas the second column is meant for the teacher to co-assess the student. 


\subsection{Setting objectives and thinking of ways to achieve them}

The teacher asks the students to put down one objective they would like to achieve first, either one from the list or their own, and to think about what they need for that. Students discuss their objectives and how they think they could achieve them in small groups. This is extremely important because they learn from each other and motivate each other. Together, they decide on the criteria for monitoring their progress. Components of the criteria to be defined with the students could be:

- what I have learnt from the activity(ies)

- $\quad$ how much effort I put into my work

- how much progress I have made in a certain area

- approximately how much time I spent on the activity (ies)

There could also be a provision against speculation: the student who does not bring any evidence of work cannot get a positive mark ( 1 - I did not pursue a goal).

Together, they also decide on the due date for their folders containing the description of their short-term objective(s) and their achievement as well as evidence of what they actually did. The questions to be answered and included in their portfolio could be structured as follows:

- What was my goal?

- Have I achieved it?

- A brief description of the activities that helped me achieve (or partly achieve) my goal.

- What have I learnt in the process?

- How satisfied am I with the outcome of my work?

- Could I have achieved my goal in another way?

The last question is also crucially important as students reflect on other, perhaps better and more efficient ways of achieving the same objective in the light of the process they have gone through. Students are also asked to include evidence (e.g. the grammar exercises they have done, the books or articles they have read, the stories, essays and/or letters they have written, the titles of the programmes they have watched) and their self-assessment, the form of which was previously discussed and agreed on e.g.:

For the work I did from to $\begin{array}{llllll}1 & 2 & 3 & 4 & 5 & \text { Explanation: }\end{array}$ (dates), I give myself grade

The teacher should collect the students' portfolios, read through their reflections, give them feedback (starting with the positive comments) and give some advice if necessary (which should create a bond between the teacher and the student).

The last point is not to be overlooked, especially if the teacher notices that a student who needs to improve a certain skill or competence repeatedly focuses on other, perhaps more pleasurable activities; however, caution on the teacher's part is absolutely necessary in order not to kill the student's motivation. The portfolio becomes a means of personal communication between 
the teacher and the student in order to help the student reach an optimal level of language competence. Comments should also include the teacher's agreement or disagreement with the student's self-assessment. The grade that has been finally agreed on must be officially recorded. Reading a student's portfolio and writing comments is time-consuming, however it is also very interesting for the teacher to find out about the student's perceptions of his/her abilities, interests, learning strategies and progress.

After the student's first experience of setting himself/herself a learning goal, attempts at achieving it and the reflection on the whole process, there should be an open discussion with everybody reporting on what should be changed in the procedure, what worked well, and whether students think this is worth continuing. Some students might have second thoughts about setting their own goals and assessing their work as they consider that to be the teacher's exclusive role, but there are always some students who realise the benefits of planning their own learning and in this way slowly becoming independent of the teacher (who certainly cannot cover all the students' needs efficiently). Listening to each other's ideas is extremely useful and also productive.

Then the teacher asks the students to set another goal for themselves, which can be to build on the first one or perhaps something else. The whole procedure is repeated, bearing in mind students' suggestions of improvements. The frequency of students working on their own goals should be agreed on in class. In the process, students learn to think about their own goals, are made aware of appropriate learning strategies, monitor their own progress much more sensitively than the teacher or tests do, build up a more positive self-image, as they are not compared with other students (but compete with themselves and aim at improvement), and gradually develop into managers of their own future.

In the third year, the goals could include preparation for the Matura tasks, e.g.:

\section{Writing}

- I can develop an argument systematically in a composition (essay) or report, emphasising decisive points and including supporting details. (B2 and Matura)

- I can write clear and detailed texts (compositions, reports or texts of presentations) on various topics related to my field of interest. (B2 and Matura)

- I can write a short review of a film or a book. (B2 and Matura)

- I can express in a personal letter different feelings and attitudes and can report the news of the day making it clear what, in my opinion, are the important aspects of an event. (B2 and Matura)

- I can write formal letters, e.g. a letter of application, complaint, enquiry. (Matura)

As students learn to identify their learning goals from the first year on, and slowly develop their learning strategies and their self-assessment ability by including conscious efforts, they should be entitled to some autonomy within the high-stakes Matura in order to lessen the negative impacts of the externally set exam. 


\subsection{Portfolio approach leading to student autonomy within the Matura exam}

As the portfolio approach (setting one's own learning goals, pursuing them, self-assessment, reflection on one's achievements and alternative ways of reaching one's learning goals) has a lot of advantages over externally set objectives and tasks, it should play a major role in the learning process and should be given credit in the school-leaving exam with its far-reaching consequences. For students and teachers to assume part of what is now externally assessed, teachers would have to be trained and standardised (a prerequisite even now for the students' own good) to be as comparable in their requirements, expectations and assessment as possible (absolute objectivity within these parameters is an unattainable goal). The skill ideally lending itself to the portfolio approach is certainly writing. In the four-year learning process, the written tasks - whose assessment is the most problematic area in the externally assessed exam as well - would be assessed by the student and the teacher. In the fourth year, students would write two essays and letters under exam conditions at their school, and would choose the two tasks they would like to be externally assessed by the subject teachers of their school (beforehand, photocopies would be given to students to make a conscious and informed decision). The tasks and their assessment, if teachers were trained and standardised, would be the responsibility of schools (the so-much-talked-about autonomy would finally be a factor). However, to avoid any kind of deviation from the Matura requirements, the chief examiner and the subject testing committee would pick students' writing tasks at random and check whether they were in line with the Matura objectives and whether teachers have assessed the assignments properly. In this way, though all the schools would be under some supervision or the threat of supervision, there would be two positive impacts: the Matura exam would be shorter, and students and teachers would be more involved in the testing process, which would play a positive role in students' learning (Leonard \& Davey 2001; Little 1994 in Harlen 2003, 201).

\section{Portfolio approach at the university level}

\subsection{Example of procedure}

Students used to assuming responsibility for their own learning at the secondary, if not already at the primary level, would naturally expect the same approach to continue at university. At the Faculty of Education in Ljubljana, the approach has been applied for several years in the Early English Language Teacher Training Programme and it seems to be working well. At the beginning of the year, students are given an introductory letter (see below) to read and discuss, first in pairs, and later together as a group. They all like the idea that they should develop their language skills and competences on their own too, as they are aware that it is themselves who know their needs best. Some proposals are then made as to what they could do as their individual work, although they are encouraged to pursue their own learning goals. They have to present their work and, after some comments are made by the presenter's colleagues (starting with the positive ones), students also reflect on what could have been done differently in the whole process, which helps presenters to see the content and the approach to their presentation from other perspectives, thus broadening everybody's experience. It is worth noting that presenters, 
apart from their own reflective evaluation, almost always include other students' ideas in their written reflections, giving their colleagues credit for them, and hopefully also using them for later reference. When the teacher gets the students' reflections (preferably in the next lesson), she reads them through and adds her own comments, starting with the positive ones, but also pointing out the language mistakes made in speaking and writing. The portfolio is returned to the student and the presenter's final task is to assess his/her work and presentation according to the criteria that were discussed and agreed on at the beginning of the year.

The teacher co-assesses the student's work and presentation and delivers the final mark; it is interesting that this total is rarely different from the student's own assessment.

The total of the points is then converted into a grade, and the average of the two grades (as two pieces of individual work are done per year) is considered to be worth one third of the final grade, the other two parts being the grades for the written (based on three tests), and the oral exam.

Conversion table: 20 - 19 points - grade 10; 18 - 17 points - grade 9; 16 - 15 points - grade $8 ; 14-13$ points - grade $7 ; 12-10$ points - grade 6

\section{Introductory letter ${ }^{1}$}

Dear Student,

Before proposing a new approach to assessment, we would like you to answer a few questions to check whether your philosophy of learning/teaching agrees with the philosophy of your teachers.

1. What do you think your role in the learning process should be?

2. What should the teacher's role be in the teaching process?

3. What skills/abilities do you need to cope with the ever changing knowledge in the world?

4. How long do you think it takes to master a foreign language?

5. What do you think the aims of this course are?

6. Would you like to be able to mark your work and then compare your mark with the teacher's? Why (not)?

7. What would you need to be able to assess your English?

8. Would you like to use the same self-assessment criteria as students in other European countries? Why (not)?

Here is our proposal to include you as an active participant in the assessment process. Besides the conventional Written and Oral Exam, we are introducing another equally important part - Individual Work. Please read a brief description of each part.

1. WRITTEN EXAM: There are three written examinations administered at equal intervals between October and June. The content of the tests will be discussed with your teacher.

2. ORAL EXAM: There is one end-of-the-year oral examination in which you demonstrate your speaking skills. You will be asked to discuss different issues in pairs.

1 This introductory letter was written by the teachers from The Early English LanguageTeacher Training Programme (Fidler, Hribar Košir, Pižorn) 
N.B. If the average of your written examinations is $\mathbf{6 5 \%}$ or above, you can be exempted from the end-of-the-year written exam. If, however, your mean is below 65\%, you will have to take the end-of-the-year examination.

3. INDIVIDUAL WORK: In addition to the written and oral exams, you will have to do a certain amount of individual work. As evidence of your learning, you will be expected to hand in two pieces of work per school year. These can include any type of language work: e.g. practising reading/writing/speaking/listening or doing exercises in grammar or vocabulary, or practising more skills at a time.

Twice a year, you will give a 10-minute presentation of your work in an interactive way, which will enable your colleagues to take an active part. After your presentation, you will have to answer the following questions in writing and hand in the reflections as well as evidence of your work:

1. What was my goal? Have I achieved it?

2. A brief description of the activities that helped me achieve (or partly achieve) my goal.

3. What have I learnt in the process?

4. How satisfied am I with the outcome of my work?

5. Could I have achieved my goal in another way?

Your work will be assessed by yourself and your teacher. Here are the proposed criteria:

1. interaction with the audience during the presentation

2 . language accuracy at the oral and written presentation

3. pronunciation and intonation

4. clarity of presentation

1. interaction with the audience during the presentation

5 can interact with a degree of fluency and spontaneity, involving the audience as much as possible

4 can interact well in prepared situations, involving the audience quite a lot

3 can interact in prepared situations, involving the audience occasionally

2 can interact in a simple way, involving the audience infrequently

2. language accuracy at the oral and written presentation

5 can speak and write freely with a high degree of accuracy

4 can speak and write freely with a satisfactory degree of accuracy

3 can use basic English with a satisfactory degree of accuracy

2 can use limited English with a satisfactory degree of accuracy

\section{3. pronunciation and intonation}

5 can pronounce and use intonation well

4 can pronounce and use intonation well in prepared situations

3 can pronounce and use intonation well in basic exchanges of information

2 can pronounce and use intonation reasonably well in basic exchanges of information 


\section{4. clarity of presentation}

5 can present clearly in a well-structured way, many types of learners are satisfied; materials/aids are clear and of good quality

4 can present well, different types of learners are satisfied; materials/aids are fairly clear and of reasonable quality

3 can present reasonably well, some types of learners are satisfied; materials/aids are not very clear

2 can present reasonably well, mostly one type of learner is satisfied; materials/aids are of poor quality

\section{SOME PROPOSALS OF CONTENT AND FORMAT OF INDIVIDUAL WORK}

Proposals refer to one piece of individual work. You can choose from the following:

READING: Five articles or a short story or a novel (the last one can be counted as two pieces of individual work, but you will have to hold two presentations: first you will report on your impressions, and then give a final presentation when you finish reading) or two poems - in each case, a two-page reflection on what you have read and what impact that has had on you.

WRITING: Essays or letters, or any kind of writing you would like to practise - between 180-200 words.

SPEAKING: A ten-minute recording and an analysis of your performance. Include your observations on word choice, grammatical structures and pronunciation - between 180-200 words.

LISTENING and VIEWING: A longer programme or a few short ones - a one-page report on what you listened to and one page of your reflection on the impact that has made on you.

LANGUAGE COMPETENCE - GRAMMAR AND VOCABULARY: We suggest that you spend approximately 7 - 8 hours on language tasks and present the exercises you have done, indicating, in two different colours, your original solutions and your corrections after consulting the key.

COMBINATION: You may decide to practise different skills. In this case you will have to consider the amount of time spent on various activities. We believe $7-8$ hours will do. Include reasons for your choice and your reflection on the work you have done.

\section{YOUR FINAL GRADE}

Your final grade will be the average of your grades in the written, oral exam and individual work, e.g. if your grades are 9 (WE), 8 (OE) and 9 (IW), your final grade will be 9 . 


\subsection{Students' response to individual work}

After a year's work, 22 students - a group of 12 fourth-year and undergraduate students, and 10 second-year students filled out the questionnaire below.

\section{Is there anything you would like to change about individual work? If yes, what?}

15 students $(68.2 \%)$ did not wish to change anything. Two students (9\%) wished to have only one presentation, one of them with no self-assessment; one student $(4.5 \%)$ wished to have suggestions of topics, two students (9\%) made an organisational proposal, one student (4.5\%) wished to do something outside the young learners' context (which was the students' own preference, but this student mistakenly thought it was obligatory) and one student (4.5\%) wished reflections to be made only orally.

\section{Do you think reflections are important or not really necessary?}

19 students $(86.49 \%)$ thought they were important, one (4.5\%) did not, and two $(9 \%)$ were undecided. What is interesting is that most of the students justified their answer, although they were not asked to do so.

\section{What, according to you, is the greatest benefit of individual work?}

Freedom of choice $4 \mathrm{x}(18.2 \%)$, experience and less afraid of public performance $1 \mathrm{x}(4.5 \%)$, getting new ideas about work and where to find literature $1 \mathrm{x}$ (4.5\%), exchange of ideas for teaching $4 \mathrm{x}$ (18.2\%), practice at speaking, pronunciation and choosing the right topic $1 \mathrm{x}(4.5 \%)$, creativity $1 \mathrm{x}$ (4.5\%), practice, motivation and speaking English $1 \mathrm{x}(4.5 \%)$, practice and interesting - useful topics $3 \mathrm{x}(13.6 \%)$, practice at writing, speaking and presentation $1 \mathrm{x}(4.5 \%)$, speaking practice $3 \mathrm{x}(13.6 \%)$, learning more $1 \mathrm{x}(4.5 \%)$, choice of topic and motivation $1 \mathrm{x}(4.5 \%)$.

It seems students appreciated freedom of choice most of all, as well as the opportunity to practise their speaking skills and exchange ideas that they might use later in their teaching careers.

\section{How do you feel about self-assessment?}

Positive comments: 17 (77.3\% - mainly pointing out being made aware of improvement or mistakes)

Negative comments: $5(22.7 \%$ - generally pointing out how difficult it is)

\section{Do you have problems deciding what grade to give yourself in each category?}
YES: $9(40.9 \%)$
NO: $10(45.5 \%)$
SOMETIMES: 3x (13.6\%)

\section{Please underline the self-assessment category you find the most difficult to assess:}

Interaction, Language accuracy, Pronunciation and intonation, Clarity of presentation (some students underlined two categories)

Interaction (1x), Language accuracy $(12 \mathrm{x})$, Pronunciation and intonation (11x), Clarity of presentation $(2 \mathrm{x})$ 


\section{Please underline the self-assessment category(ies) you find easy to assess:}

Interaction, Language accuracy, Pronunciation and intonation, Clarity of presentation (some students underlined two categories)

Interaction (18x), Language accuracy (0x), Pronunciation and intonation (1x), Clarity of presentation (13x)

Students found language accuracy as well as pronunciation and intonation the most difficult categories to assess, whereas interaction and clarity of presentation seemed easier to assess, although their self-assessment did not indicate those categories as more or less problematic.

The content of individual work was chosen by the students, so in this respect they were completely autonomous. The assessment of their individual work, however, was a reflective process leading to the agreement between the teacher and the student. Students tended to be too modest at the beginning, but after their first self-assessment and the teacher's coassessment they became quite realistic about their performance. Giving themselves a higher grade happened very rarely. Some students took more time to realise that it was mainly them who should be in control of their learning progress; however, this experience, although having come with some delay, was also precious for their own personal growth. In the course of time, students became more reflective and responsible, i.e. started to express specific wishes regarding the content of the lessons. The teacher's heavy burden of assessing students' work on her own was also made much lighter.

\section{Conclusion}

The portfolio approach, although rather time-consuming, is rewarding for both teachers and students as they become more aware of different goals to be reached and also of the many ways in which to do so. Both become more engaged in the learning-teaching process, which they experience as a personal challenge and not something imposed on them. Students observe their own progress, which motivates them to do further work, and their learning goals, even during 'regular' class work, become more clearly defined. In the process, the teacher and students learn a lot from and about each other (also about their own failures), and become partners searching for the best ways for each student to learn in an efficient and personally adjusted way.

Bearing all this in mind, autonomy, as a result of the portfolio approach, should not only be a nice word written down in the documents of our educational policy, but should play a significant role in the exams as well. 


\section{Bibliography}

Anderson, J, 0., and D. G. Bachor. 1998. A Canadian Perspective on Portfolio Use in Student Assessment. Assessment in Education: Principles, Policy \& Practice 5, no. 3: 353-79.

Broadfoot, P. 1998. Records of Achievement and The Learning Society: a tale of two discourses. Assessment in Education: Principles, Policy \& Practice 5, no. 3: 447-77.

Council for Cultural Co-operation, Education Committee. 2000. (Working material). European Language Portfolio, Recommendations. Principles and Guidelines. Strasbourg: Council of Europe.

Čok, L. 1999. Portfolio of Languages in Slovenia. Content, procedures and phases of trial implementation in Slovenia 1998 - 2001. In Izobraževanje učiteljev za prenovljeno šolo, eds. J. Hytönen, C. Razdevšek Pučko, and G. Smyth, 97-101. Ljubljana: Pedagoška fakulteta.

Gipps, C.V. 1994. Beyond Testing. Towards a theory of educational assessment. London, Washington: The Falmer Press.

Fidler, S. 2000. Jezikovni portfolio pri pouku angleščine. Unpublished MA Dissertation. Ljubljana: Filozofska fakulteta.

Harlen, W., and R. D. Crick. 2003. Testing and Motivation for Learning. Assessment in Education: Principles, Policy \& Practice 10, no. 2: 169-207.

Little, D., and R. Perclová. 2001. European Language Portfolio. Guide for Teachers and Teacher Trainers. Modern Languages Division. Strasbourg: Council of Europe.

McDonald, B., and D. Boud. 2003. The Impact of Self-assessment on Achievement: the effects of self-assessment training on performance in external examinations. Assessment in Education: Principles, Policy \& Practice 10, no. 2: 209-20.

Oskarsson, M. 1992. Self-assessment of foreign language skills: a survey of research and development work. Modern languages. Strasbourg: Council of Europe. 